\title{
Differentiated Thyroid Cancer with Thyroglobulin Elevation and Negative Iodine Scintigraphy (TENIS Syndrome)
}

\author{
Raja Sfar',2, Tarek Kamoun1,2, Manel Nouira ${ }^{2,3}$, Hamza Regaieg2,3, Nouha Ammar ${ }^{2,3}$, \\ Hela Charfi, ${ }^{1,2}$, Achraf Bahloul', Maha Ben Fredj',3, Kaouther Chatti',2, Mohsen Guezguez ${ }^{2,3}$, \\ Habib Essabbah ${ }^{1,2}$ \\ ${ }^{1}$ University of Monastir, Monastir, Tunisia \\ ${ }^{2}$ Department of Nuclear Medicine, Sahloul Hospital, Sousse, Tunisia \\ ${ }^{3}$ Sousse University, Sousse, Tunisia \\ Email: sfarraja@yahoo.fr
}

Received 10 April 2014; revised 8 May 2014; accepted 5 June 2014

Copyright (C) 2014 by authors and Scientific Research Publishing Inc.

This work is licensed under the Creative Commons Attribution International License (CC BY). http://creativecommons.org/licenses/by/4.0/

c) (i) Open Access

\section{Abstract}

Background and Objectives: Following the initial management, some patients with differentiated thyroid cancer (DTC) develop a state of high thyroglobulin (Tg) and Negative Iodine Scintigraphy. The predisposing factors and outcome of this condition are unclear. In this study, our objectives were to analyze the characteristics of patients with high Tg level and negative Iodine scintigraphy and to determine the predictive factors for development of high $\mathrm{Tg}$ and negative scintigraphy. Patients and Methods: Retrospective study of 34 patients undergoing treatment for DTC, followed in the Nuclear Medicine department of the University Hospital-Sahloul Sousse between 1990 and 2006 and having a high Tg and negative Iodine scintigraphy. Fourteen patients had Tg between 2 and $10 \mathrm{ng} / \mathrm{ml}, 16$ had Tg between 11 and $100 \mathrm{ng} / \mathrm{ml}$ and 4 patients had Tg more than $100 \mathrm{ng} / \mathrm{ml}$. Results: There were 25 women and 9 men. The mean age was 51.65 years. In $\mathbf{9 4 . 1 \%}$ of cases, the tumor was papillary carcinoma. Follicular tumors accounted for only $5.9 \%$. The mean nodule size was $3.26 \mathrm{~cm}$. Capsular invasion was seen in $47.1 \%$ cases. The locoregional invasion was found in $35.3 \%$. The lymph node extension was found in $84.8 \%$ of patients having lymph node surgery. Lymph node involvement was observed in $92.8 \%$ of patients with papillary cancer but it was found in $\mathbf{7 . 2 \%}$ of patients with follicular cancers. Lymph node invasion was unilateral in $28.6 \%$ (N1a) and bilateral, contralateral or mediastinal in $71.4 \%$ (N1b). Initial level of Tg was as follows: 7 patients had Tg between 2 and $10 \mathrm{ng} / \mathrm{ml}, 14$ patients had Tg between 11 and $100 \mathrm{ng} / \mathrm{ml}$ and $12 \mathrm{had} \mathrm{Tg}$ more than $100 \mathrm{ng} / \mathrm{ml}$. The mean number of radioactive Iodine cure was 11.08 for patients with $T g$ more than $100 \mathrm{ng} / \mathrm{ml}$ with a significant difference $(P=$ 0.001). Conclusion: Among epidemiological, pathological and clinical characteristics, lymph node invasion is the most frequent parameter found in patients with a DTC with high Tg level and nega- 
tive Iodine scintigraphy.

Keywords

Differentiated Thyroid Cancer, Thyroglobulin, Iodine, Scintigraphy, TENIS Syndrome

\section{Introduction}

Thyroid cancer is the most common endocrine malignancy. More than $90 \%$ of primary thyroid cancers are differentiated papillary or follicular types. The treatment of thyroid carcinoma consists of total thyroidectomy and radioactive iodine ablation therapy, followed by L-thyroxine therapy [1]. Follicular and papillary thyroid cancer (frequently called differentiated thyroid cancer (DTC)) have good prognosis. Iodine scintigraphy and thyroglobulin (Tg) are the best tools for monitoring DTC after total thyroidectomy. A detectable Tg associated with a negative scintigraphy is not a rare situation.

The objectives of our work were to analyze the characteristics of patients with a high Tg level and negative Iodine scintigraphy and to determine the predictive factors for development of high $\mathrm{Tg}$ and negative scintigraphy (Tg+/scan-).

\section{Patients and Methods}

Retrospective study of 34 patients undergoing DTC, followed in the Nuclear Medicine department of the University Hospital of Sahloul Sousse between 1990 and 2006 and having a high final Tg and negative Iodine Scintigraphy. The thyroglobulin level was measured 4 weeks after L-thyroxine withdrawal (Tg-off, TSH > 20 $\mathrm{mU} / \mathrm{l}$ ). Prior to treatment, post-therapeutic whole body scanning (WBS) was performed 5 days after the administration of $3700 \mathrm{MBq}{ }^{131} \mathrm{I}$. Tg is measured by immunoradiometric assay (IRMA). The identified patients were divided into three groups: 1) 14 patients had Tg between 2 and $10 \mathrm{ng} / \mathrm{ml}, 2) 16$ had a Tg between 11 and 100 $\mathrm{ng} / \mathrm{ml}$ and 3) 4 patients had a Tg more than $100 \mathrm{ng} / \mathrm{ml}$.

\section{Results}

A total of 34 patients were identified, There were 25 women and 9 men $($ Sex ratio $=2.77$ ).

The mean age of these patients was 51.65 years with extremes ranging from 26 to 83 years. The distribution of patients by age group showed a higher incidence (9/34 patients) between 41 and 50 years.

In $94.1 \%$ of cases, the tumor was papillary cancer. Follicular tumors accounted for only $5.9 \%$ of cases. The average age of our patients was 51.2 years ( \pm 16 years) for papillary cancer and 59 ( \pm 7 years) for follicular cancer, with no difference significant $(\mathrm{P}=0.5)$. The mean nodule size was $3.26 \mathrm{~cm}$. It is less important in papillary carcinomas than in the follicular type but the difference is not signficant $(P=0.47)$ (Table 1 ).

The capsule invasion was seen in $47.1 \%$ of cases. The locoregional invasion was found in $35.3 \%$ of patients.

Central lymph node dissection with or without a lateral dissection was performed in 33 patients, representing $97.1 \%$ of cases. The lymph node extension was found in $84.8 \%$ (28/33) of patients having lymph node surgery. Lymph node involvement was observed in $92.8 \%$ of patients with papillary cancer but it was found in $7.2 \%$ of patients with follicular cancers.

Lymph node metastasis was unilateral in $28.6 \%$ (N1a) and bilateral, controlateral or mediastinal in $71.4 \%$ (N1b).

Initial level of Tg was as follows: 8 patients had Tg between 2 and $10 \mathrm{ng} / \mathrm{ml}, 14$ patients had Tg between 11 and $100 \mathrm{ng} / \mathrm{ml}$ and 12 had Tg more than $100 \mathrm{ng} / \mathrm{ml}$.

Follicular carcinoma secreted more Tg than papillary (354 ng/ml versus $145 \mathrm{ng} / \mathrm{ml}$ ) but with no significant difference $(\mathrm{P}=0.2$ ) (Table 2).

We also studied the mean value of Tg according to the tumor size and we noted that tumor of size between 2.1 and $3 \mathrm{~cm}$ secreted more Tg (Table 3 ).

Patients having Tg more than $100 \mathrm{ng} / \mathrm{ml}$, had more lymphatic invasion and locoregional extension than patients having Tg with a significant difference $(\mathrm{P}<0.05)$ (Table 4, Table 5). 
Table 1. Mean size of tumor according to histological type.

\begin{tabular}{cc}
\hline Histological type & Mean size (cm) \\
\hline Papillary & $3.18 \pm 2.33$ \\
Follicular & $4.5 \pm 4.95$ \\
\hline
\end{tabular}

Table 2. Initial Tg according to the histological type.

\begin{tabular}{ccccc}
\hline Histological type & Number & Mean value of Tg & Standard deviation & P \\
\hline Papillary carcinoma & 32 & $145 \mathrm{ng} / \mathrm{ml}$ & 206.8 & $\mathbf{0 . 2}$ \\
Follicular carcinoma & 2 & $354 \mathrm{ng} / \mathrm{ml}$ & 489.32 & \\
\hline
\end{tabular}

Table 3. Initial Tg according to the tumor size.

\begin{tabular}{cccc}
\hline Tumor size & Number & Mean value of Tg & Standard deviation \\
\hline$<\mathbf{1} \mathbf{~ c m}$ & 1 & $93 \mathrm{ng} / \mathrm{ml}$ & - \\
$\mathbf{1} \mathbf{-} \mathbf{~ c m}$ & 13 & $103.38 \mathrm{ng} / \mathrm{ml}$ & 186.36 \\
$\mathbf{2 . 1} \mathbf{-} \mathbf{~ c m}$ & 11 & $302.1 \mathrm{ng} / \mathrm{ml}$ & 274.06 \\
$>\mathbf{3} \mathbf{~ c m}$ & 9 & $83.49 \mathrm{ng} / \mathrm{ml}$ & 162.7 \\
\hline
\end{tabular}

Table 4. Initial Tg according to lymphatic invasion.

\begin{tabular}{cccc} 
& & Lymphatic invasion & \\
\cline { 2 - 4 } & & No & Yes \\
\hline \multirow{3}{*}{ Initial Tg value } & $2-10$ & 4 & 4 \\
& $11-100$ & 1 & 12 \\
& $>100$ & 1 & 12 \\
\hline
\end{tabular}

Table 5. Initial Tg according to locoregional extension.

\begin{tabular}{cccc} 
& & Locoregional extension & \\
\cline { 2 - 4 } & & No & Yes \\
\hline \multirow{3}{*}{ Initial Tg value } & $2-10$ & 5 & 2 \\
& $11-100$ & 11 & 3 \\
& $>100$ & 5 & 7 \\
\hline
\end{tabular}

Postoperative WBS showed cervical uptake in 29 cases, cervical, pulmonary and mediastinal uptake in one case, cervical and lung uptake in two cases and cervical and bone uptake in two cases.

Final level of Tg was as follows: 14 patients had Tg between 2 and 10 ng/ml, 16 had a Tg between 11 and 100 $\mathrm{ng} / \mathrm{ml}$ and 4 patients had a Tg more than $100 \mathrm{ng} / \mathrm{ml}$.

The mean number of radioactive Iodine cures was 11.08 for patients with $\mathrm{Tg}$ more than $100 \mathrm{ng} / \mathrm{ml}$ with a significant difference $(\mathrm{p}=0.001)$ (Tables 6-8).

\section{Discussion}

Primary treatment of differentiated thyroid carcinoma consists of total thyroidectomy and lymph node (LN) dissection. The most part of literature considers prophylatic central neck dissection (PCND). The role of PCND in DTC is unclear and controversial. The advantages of PCND are: removal of the central LN that potentially harbor micro-metastases, more accurate staging of disease in order to plan more individualized management, reducing the need for re-operation to remove the metastatic LN which have developed later and possible improvement in overall survival. The disadvantages are: an extensive surgery but lack of evidence of survival benefit, higher incidence of complications with little impact on local recurrence rate, possibility of over treating in some cases (N0) patients and it does not sound like a cost effective approach in the management of tumors of 
Table 6. Number of patients according to the_administered ablative activity.

\begin{tabular}{cccc}
\hline & & Number of patients & Percentage \\
\hline & $<300$ & 9 & 26.5 \\
& $301-500$ & 8 & 23.5 \\
Per cure administered & $501-1000$ & 9 & 26.5 \\
ablative activity (mci) & $1001-1500$ & 6 & 17.6 \\
& $>1500$ & 2 & 5.9 \\
\hline
\end{tabular}

Table 7. Mean activity according to initial Tg.

\begin{tabular}{cc} 
Initial Tg value & Mean activity (mCi) \\
\hline $\mathbf{2}-\mathbf{1 0}$ & $448.57 \pm 365.88$ \\
$\mathbf{1 1}-\mathbf{1 0 0}$ & $471.43 \pm 209.13$ \\
$>\mathbf{1 0 0}$ & $1098.33 \pm 563.22$ \\
\hline
\end{tabular}

Table 8. Number of iodine cures according to Tg.

\begin{tabular}{ccccc}
\hline & & $\begin{array}{c}\text { Number of } \\
\text { patients }\end{array}$ & $\begin{array}{c}\text { Mean number of } \\
\text { iodine cures }\end{array}$ & Standard deviation \\
\hline Initial Tg value & $2-10$ & 7 & 4.71 & 3.68 \\
& $11-100$ & 14 & 4.71 & 2.09 \\
& $>100$ & 12 & 11.08 & 5.68 \\
\hline
\end{tabular}

smaller size [1]. Surgery is followed by radioactive iodine (RAI) to destroy thyroid tissue remnants and possible metastases.

After complete destruction of remnants, metastases or recurrence can be detected by measurement of the serum Tg level as well as by radionuclide methods [2].

The most part of guidelines suggest that RAI is not recommended for patients with Tg less than 10 , in classical DTC less $1 \mathrm{~cm}$, and recommended for patients with distant metastases, lymph node invasion, extrathyroidal extension, tumor size $>1 \mathrm{~cm}$ [3] [4].

For the great majority of patients with follicular and papillary thyroid cancer, the prognosis is quite good. DTC concentrates Iodine-131 ( $\left.{ }^{131} \mathrm{I}\right)$ by trapping (the function of the sodium iodine symporter, or NIS) and organifying the iodide ion to produce levothyroxine and triiodothyronine.

In a minority of patients the diagnostic follow-up scan shows no functioning thyroid tissue, but the serum Tg, specific to differentiated, non-C-cell thyroid tissue, is still elevated [5].

If this Tg-elevated negative iodine scintigraphy syndrome is present, it must be investigated by other radiologic techniques: ultrasound (US), computed tomography (CT), positron emission tomography (PET), or magnetic resonance imaging (MRI) to find metastatic disease, and collaborate with an experienced surgeon in removing such metastases [6].

The discussed causes TENIS syndrome presentation in DTC are anti-Tg antibody, microscopic remnants of normal tissue or of metastatic disease not visible with the diagnostic activity of ${ }^{131} \mathrm{I}$, inadequate serum TSH stimulation, macroscopic metastatic disease that has mutated to lose NIS, or a combination of these factors [3]-[7]. Some authors found that Serum heterophile antibodies can also cause a false elevation of serum Tg. Heterophile antibodies should be suspected and sought when the Tg level does not equate with the clinical and imaging findings and does not increase and decrease appropriately with TSH elevation and suppression [7]-[9].

The physician must decide at what level of serum Tg further investigation is necessary. The American Thyroid Association guidelines suggest level of stimulated Tg $2 \mathrm{ng} / \mathrm{ml}$ as a diagnostic threshold [9]. Other experts are satisfied if the stimulated tg remains $10 \mathrm{ng} / \mathrm{ml}$ [10]-[12].

In the present study, 7/34 patients had Tg more than $10 \mathrm{ng} / \mathrm{ml}$. These patients had probably anti-tg antibody interference, 27/34 patients, who had Tg more than $10 \mathrm{ng} / \mathrm{ml}$, had more lymph node invasion and locoregional extension than patients having Tg less than $10 \mathrm{ng} / \mathrm{ml}$ with a significant difference $(\mathrm{P}<0.05)$. These patients had probably microscopic remnants of normal tissue or metastatic disease not visible with the diagnostic dosage of 
${ }^{131}$ I or macroscopic metastatic disease that has mutated to lose NIS.

If we cannot locate operable metastases and/or tumor location remains elusive, empiric high-dose ${ }^{131}$ I therapy, should be considered. There are no randomized studies to prove that this treatment prolongs life, although there is definite evidence of cell killing, because the serum Tg level frequently diminishes after radioiodine therapy. In selected cases, external beam radiotherapy will be helpful when the tumor has been located but cannot be fully removed [3].

\section{Conclusion}

Among epidemiological, pathological and clinical characteristics, lymph node, and locoregional invasion are the most frequently found parameter in patients with a DTC with high Tg level and negative Iodine scintigraphy. A good knowledge of these factors and causes of TENIS syndrome are required to ensure better management of patients.

\section{References}

[1] Chen Chan, A., Hin Lang, B.H. and Pun Wong, K. (2003) The Pros and Cons of Routine Central Compartment Neck Dissection for Clinically Nodal Negative (cN0) Papillary Thyroid Cancer. Gland Surgery, 2, 186-195.

[2] Pagano, L., Klain, M., Pulcrano, M., et al. (2004) Follow-Up of Differentiated Thyroid Carcinoma. Minerva Endocrinologica, 29, 161-174.

[3] Cooper, D., Doherty, G.M., Haugen, B.R., et al. (2009) Revised American Thyroid Association Management Guidelines for Patients with Thyroid Nodules and Differentiated Thyroid Cancer. Thyroid, 19, 1-44. http://dx.doi.org/10.1089/thy.2009.0110

[4] Luster, M., Clarke, S.E., Dietlein, M., et al. (2008) Guidelines for Radioiodine Therapy of Differentiated Thyroid Cancer. European Journal of Nuclear Medicine and Molecular Imaging, 35, 1941-1959. http://dx.doi.org/10.1007/s00259-008-0883-1

[5] Edward, B. (2011) The Problem of the Patient with Thyroglobulin Elevation but Negative Iodine Scintigraphy: The TENIS Syndrome. Seminars in Nuclear Medicine, 41, 113-120. http://dx.doi.org/10.1053/j.semnuclmed.2010.10.002

[6] Mazzaferri, E.L. (2005) Empirically Treating High Serum Thyroglobulin Levels. Journal of Nuclear Medicine, 46, 1079-1086.

[7] Preissner, C.M., O’Kane, D.J., Singh, R.J., et al. (2003) Phantoms in the Assay Tube: Heterophile Antibody Interference in Serum Thyroglobulin Assays. The Journal of Clinical Endocrinology and Metabolism, 88, 3069-3074. http://dx.doi.org/10.1210/jc.2003-030122

[8] Mazzaferri, E.L., Robbins, R.J., Spencer, C.A., et al. (2003) A Consensus Report of the Role of Serum Thyroglobulin as a Monitoring Method for Low-Risk Patients with Papillary Thyroid Carcinoma. The Journal of Clinical Endocrinology and Metabolism, 88, 1433-1441. http://dx.doi.org/10.1210/jc.2002-021702

[9] Clark, O.H. and Hoelting, T. (1994) Management of Patients with Differentiated Thyroid Cancer Who Have Positive Serum Thyroglobulin Levels and Negative Radioiodine Scans. Thyroidology, 4, 501-505. http://dx.doi.org/10.1089/thy.1994.4.501

[10] Dottorini, M.E., Vignati, A., Mazzuccheli, L., et al. (1997) Differentiated Thyroid Cancer in Children and Adolescents: A 37 Year Experience in 85 Patients. Journal of Nuclear Medicine, 38, 669-675.

[11] Pacini, F., Agate, L., Elisei, R., et al. (2001) Outcome of Differentiated Thyroid Cancer with Detectable Serum Thyroglobulin and Negative Diagnostic Iodine Whole Body Scan: Comparison of Patients Treated with High I-131 Activities versus Untreated Patients. The Journal of Clinical Endocrinology and Metabolism, 86, 4092-4097. http://dx.doi.org/10.1210/jcem.86.9.7831

[12] Rosário, P.W., Maia, F.C., Barroso, A.L. and Purisch, S. (2005) Investigating Patients with Differentiated Thyroid Carcinoma and Elevated Serum Thyroglobulin but Negative Whole-Body Scan. Arquivos Brasileiros de Endocrinologia \& Metabologia, 49, 246-252. 
Scientific Research Publishing (SCIRP) is one of the largest Open Access journal publishers. It is currently publishing more than 200 open access, online, peer-reviewed journals covering a wide range of academic disciplines. SCIRP serves the worldwide academic communities and contributes to the progress and application of science with its publication.

Other selected journals from SCIRP are listed as below. Submit your manuscript to us via either submit@scirp.org or Online Submission Portal.
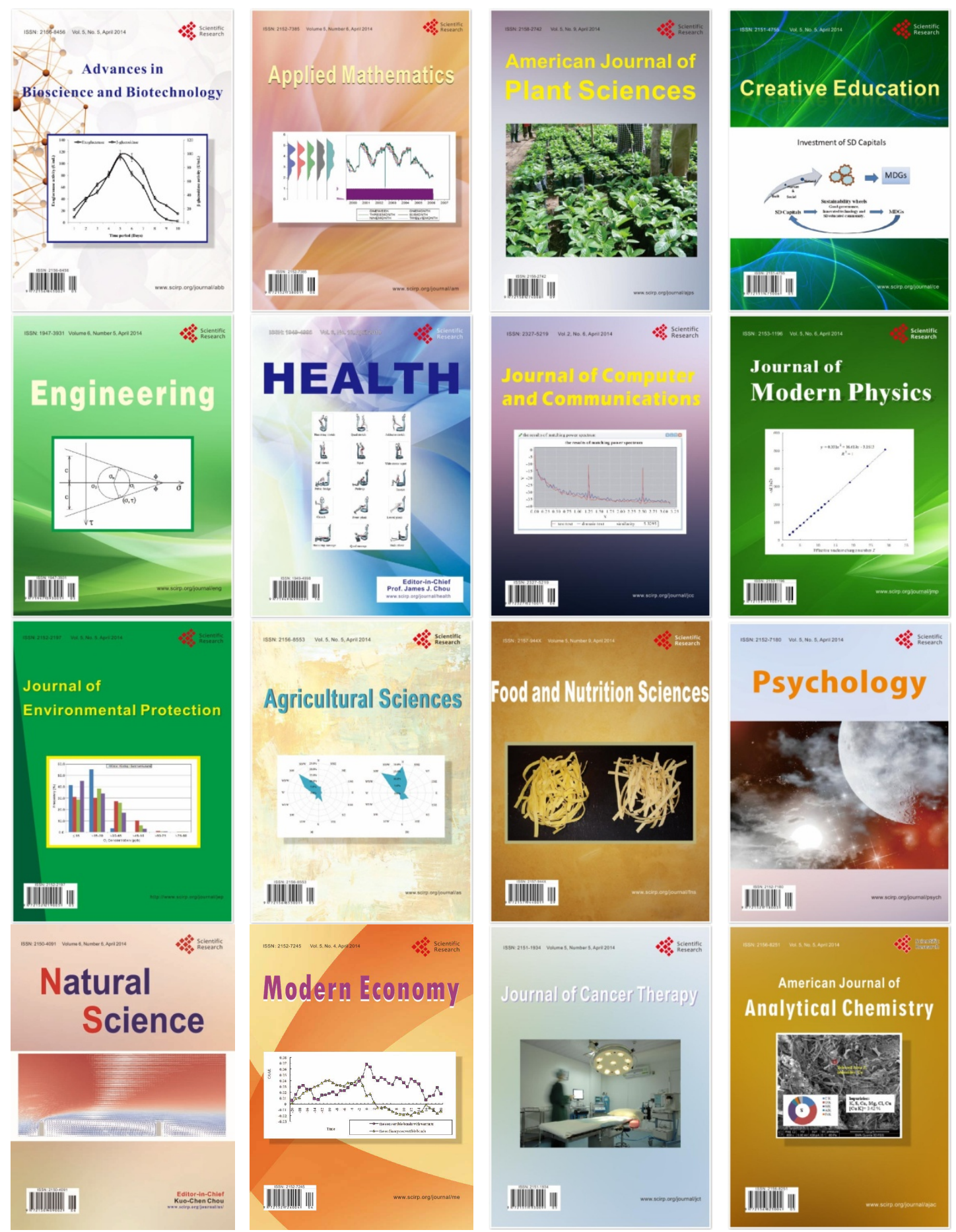